\title{
FAKTOR-FAKTOR YANG MEMPENGARUHI PERILAKU MASYARAKAT TERHADAP KEPATUHAN PENGGUNAAN APD (ALAT PELINDUNG DIRI) PADA MASA PANDEMI COVID-19 DI DESA SUKA MAJU
}

\author{
TATI MURNI KAROKARO', ADE MULIANI ${ }^{2}$, RAHMAD GURUSINGA ${ }^{3}$, \\ KARDINA HAYATI ${ }^{4}$, MILA GUSTIA ${ }^{5}$ \\ Institut Keseharan Medistra Lubuk Pakam \\ Fakultas Keperawatan Dan Fisioterapi, \\ Program Studi Keperawatan Jenjang Sarjana, \\ Jl. Sudirman No. 38 Lubuk Pakam, Kab. Deli Serdang \\ E-mail: tatikarokaro612sp@gmail.com \\ DOI : https://doi.org/10.35451/jkg.v4i1.790
}

\begin{abstract}
December 2019 witnessed the discovery of a new virus in Wuhan, China, namely Corona Virus Diseases (COVID-19). This is the latest epidemic to hit the world. Covid-19 belongs to the same coronavirus family as the cause of SARS and MERS, but the mortality rate for SARS and MERS is higher than Covid-19 and Covid-19 has a wider and faster spread. The way to protect yourself from exposure to Covid-19 is to reduce such as washing your hands in running water; seek information related to COVID-19 from valid sources, know what to do if you are sick. PSBB is regulated by the Minister of Health Regulation (RI Number 9 of 2020 concerning Guidelines for Large-Scale Social Restrictions in the Context of Accelerating the Handling of Corona Virus Disease 2019 (Covid-19) to prevent the possibility of spreading good behavior that can be an effort to prevent the transmission of Covid-19 Health behavior is determined by Many factors include knowledge, perception, emotion, motivation, and the environment towards the use of personal protective equipment during the Covid-19 period in Suka Maju Village, Singingi Hilir District, Kuantan Singingi Regency, Riau Province using inclusion criteria, using a closed questionnaire. Based on this study, it was found that respondents who obeyed the use of PPE were influenced by 74 respondents $(93.7 \%) ., 3 \%)$ It is recommended to the community to continue to run the Health protocol by using PPE.
\end{abstract}

Keywords: Community behavior factors, Use of PPE during the Covid-19 pandemic. 


\section{PENDAHULUAN}

Masalah kesehatan yang di alami dunia pada saat ini merupakan hal yang menarik perhatian dunia karena menarik perhatian dari pakar-pakar Kesehatan dan masyarakat luas yaitu suatu virus yang di sebut virus corona. Corona Virus-19 atau yang lebih populer dengan istilah COVID-19 telah ditetapkan oleh WHO. Pada akhir Bulan Desember tahun 2019 terjadi penemuan virus baru di Wuhan, China yaitu Corona Virus Deases (COVID-19). Virus ini menjadi wabah terbaru yang menyerang dunia. Pada awalnya, virus ini menyerang daerah Wuhan dengan menyebabkan sekitar 90.308 orang terinfeksi, dengan kematian mencapai 3.087 orang atau $6 \%$, dan pasien yang sembuh mencapai 45.726 orang (Kementerian Kesehatan, 2020).

Secara resmi tanggal 12 Februari 2020 WHO dengan resmi menyatakan bahwa penyakit coronavirus dengan nama Coronavirus Disease 2019 (Covid-19). Covid19 termasuk dalam bagian coronavirus dimana penyebabnya hamper sama dengan SARS dan MERS, namun angka kematian akibat SARS dan MERS lebih tinggi dibanding Covid-19 dan Covid-19 memiliki penyebaran yang lebih luas dan cepat ((Tim Kerja Kemendagri, 2020) dalam Octaviani. R, 2020). Virus ini pertama sekali terjadi di Wuhan, kasus Covid-19 terus meningkat pada akhir Bulan Januari hingga awal Bulan Februari 2020. Laporan kasus umumnya berasal dari Hubei dan provinsi-provinsi disekitar, hingga seluruh Negara. Pada Bulan Februari 2021, jumlah yang terinfeksi Covid19 di seluruh dunia telah mencapai $111,419,939$ kasus, dan jumlah yang meninggal dunia adalah $2,470,772$ orang. Angka kejadian yang paling besar di Amerika Serikatmencapai 27,828,370 disusul India, Brazil dan Rusia (WHO, 2021).

Covid-19 pertama kali dilaporkan masuk ke Indonesia pada tanggal 02 Maret 2020 dengan kasus sebanyak 2 orang yang berasal dari daerah Depok dan terus bertambah setiap harinya hingga terjadi penyebaran kasus menginfeksi ke seluruh provinsi di
Indonesia tepatnya pada tanggal 06 Mei 2020 (Kemenkes.go.id,2020) dalam Octaviani. R. 2020). Tanggal 08 Mei 2020 angka kejadian di Indonesia menempati urutan ke-36 di dunia dan urutan ke-2 se ASEAN setelah Negara Singapura dengan jumlah 21,707, sedangkan jumlah kematian di Indonesia akibat Covid-19 yaitu 7,19\%. Selain Indonesia angka kematian tertinggi di ASEAN juga terdapat di Negara Filiphina dengan tingkat angka $6,65 \%$ ((Worldmeters.info, 2020) dalam Octaviani. $R, 2020)$.

Kasus Covid-19 pada Bulan Februari 2021 di Indonesia kini sudah memakan korban sebanyak 1,32 Juta jiwa, dengan pasien sembuh sebanyak 1,13 juta dan pasien meninggal sebanyak 35,876 jiwa. Daerah di Indonesia yang menduduki pringkat tertinggi pada Bulan Februari 2021 diduduki oleh Daerah Jakarta dengan kasus sebanyak 336,000 jiwa, dengan pasien sembuh sebanyak 321,000 jiwa, dan pasien meninggal sebanyak 5,408 jiwa. Sedangkan Riau menduduki pringkat ke-7 setelah Jawa Barat, Jawa Tengah, Jawa Timur, Sulawesi Selatan, Kalimantan Timur, dan Bali. Dengan kasus di Riau sebanyak 31,286 jiwa, dengan jumlah pasien sembuh sebanyak 29,417 jiwa dan meninggal sebanyak 612 jiwa (JHU CSSE COVID-19,2021).

Kasus Covid-19 di Kabupaten Kuantan Singingi dimulai pada tanggal 03 Maret 2020 hingga 25 Maret 2021 ditemukan suspek sebanyak 9.052 jiwa dan terkonfirmasi sebanyak 829 jiwa. Untuk di Kecamatan Singingi Hilir ditemukan sebanyak 82 jiwa dengan pasien isolasi mandiri 1 orang, isolasi di Rumah Sakit 1 orang, pasien sembuh 78 orang dan meninggal 2 orang. Pada awal Bulan Juni 2020 ditemukan masyarakat Desa Suka Maju terpapar Covid-19, yang diawali oleh salah seorang warga yang berdomisili di Batam dan melakukan kunjungan ke wiliyah Desa Suka Maju dan menetap selama 2 bulan. Warga tersebut diketahui saat Ia hendak kembali ke daerah asalnya dan melakukan rangkaian tes di RSUD Arifin Ahmad, Pekanbaru. Setelah melakukan tes 
ditemukan bahwasannya beliau terpapar Covid-19. Setelah ditindak lanjuti, maka masyarakat Desa Suka Maju dilakukan Tracing atau swab masal. Setelah itu ditemukan warga yang positif Covid-19 sebanyak 3 orang dari Desa Suka Maju (riauonline.co.id 2020). Akibat tingginya angka penyebaran virus Covid-19 di Indonesia, pemerintah membuat kebijakan Pembatasan Sosial Berskala Besar (PSBB) dengan mengesahkan Peraturan Pemerintah (PP) No. 21 Th 2020. Dengan tujuan PSBB sebagai upaya pemutus rantai penyebaran dan melawan Covid-19 di Indonesia yang disampaikan melalui rapat terbatas kabinet yang diadakan pada tanggal 31 Mei 2020.

Selain adanya kebijakan dari pemerintah, masyarakat juga dihimbau untuk meningkatkan Prilaku Hidup Bersih Dan Sehat (PHBS). Di Saat pandemic Covid-19, perilaku hidup bersih dan sehat (PHBS) adalah salah satu Tindakan yang dapat diterapkan untuk mencegah penyebaran infeksi Covid-19 (Kementerian Kesehatan, 2020). Mencuci tangan dengan menggunakan air bersih dan sabun, makansayur dan buah, serta melakukan aktivitas fisik dengan rutin diharapkan mencegah terinfeksi Covid-19. Perilaku tersebut kiranya dapat di sampikan ke masyarakat lewat promosi kesehatan penggunaan masker serta menjaga jarak. Cara melindungi diri dari paparan Covid-19 adalah dengan mengurangi resiko seperti mencuci tangan di air mengalir; mencari informasi terkait COVID-19 dari sumber yang valid, mengetahui apa saja yang harus dilakukan bila sakit (Rosidin. U, 2020).

Sosialisasi yang dilakakukan untuk mencegah penularan Covid-19 yaitu melalui PHBS, Gerakan Masyarakat (GERMAS), penggunaan masker, menjaga jarak dan penggunaan desinfektan. Kegiatan sosialisasi bertujuan untuk memberikan pengetahuan kepada masyarahat agar tetap menjaga lingkungan dan pola hidup bersih dan sehat, sehingga masyarakat dapat terhindar penyakit infeksi seperti Covid-19.
(Sulaeman dan Supriadi, 2020) dalam Malik. F. 2020).

Setiap individu yang sehat maupun penderita dengan gejala Covid-19, penting menerapkan PHBS, isolasi mandiri di rumah, dan menjaga jaraksebagai upaya pencegahan penularan Covid-19. Penularan virus dapat terjadi lewat droplet yang menempel pada benda dapat kita dicegah dengan mematuhi etika saat batuk dan bersin yaitu dengan cara menggunakan tisu yang menutup mulut dan hidung atau dapat juga dilakukan dengan menggunakan lipatan siku tangan ketika batuk atau bersin, serta membuang tisu yang sudah di gunakan ke dalam tempat sampah, mencuci tangan dengan air mengalir menggunakan sabun, atau pembersih tangan berbasis alcohol (sanitizer) agar dapat memutus mata rantai virus. Upaya-upaya yang sudah di lakukan tersebut juga disertai dengan asupan gizi yang baik agar dapat meningkatkan daya tahan tubuh dan immundalam menghadapi Covid-19 (Malik. F. 2020).

Faktor yang mempengaruhi perilaku seperti persepsi, pengetahuan, motivasi, emosi, dan lingkungan. Beberapa komponen yang mempengaruhi perilaku Kesehatan masyarakat seperti persepsi tentang kerentanan penyakit, hambatan dalam upaya pencegahan, manfaat dan adanya dorongan, serta persepsi tentang kemampuan yang dimiliki untuk melakukan upaya pencegahan. Sebaliknya perilaku masyarakat yang kurang baikdapat meningkatkan angka kejadian dan angka kematian akibat penularan Covid-19 (Dewi. I. P. dkk, 2020)

Perubahan perilaku dan individu dipengaruhi oleh tingkat pengetahuan dan keterampilan melalui proses belajar. Dengan demikian perilaku masyarakat yang masih negative dapat diupayakan melalui edukasi oleh pihak-pihak yang berwenang seperti forum kesehatan desa atau sejenisnya dalam upaya pelaksanaan kegiatan yang dimaksud (Kementerian Kesehatan, 2020). Hasil penelitian sebelumnya didapatkan pengetahuan masyarakat tentang Covid19 
Baik (90\%) dan cukup 10\%. Perilaku masyarakat didapat baik $95,8 \%$ dan cukup $4,2 \%$. Dapat disimpulkan bahwa ada hubungan yang bermakna antara pengetahuan dengan perilaku masyarakat tentang Covid-19 dengan nilai $P \quad 0,047$ $(<0,05)$. Perilaku baik yang dimaksud tersebut merupakan perilaku pencegahan covid-19 seperti perilaku mencuci tangan menggunakan Sabun maupun handsanitizer, tetap menjaga jarak,tidak menghadiri kegiatan yang menimbulkan keraimaian, dan tetap di rumah. (Rosidin. U, 2020).

Dari hasil survey yang dilakukan terhadap masyarakat Desa Suka Maju didapatkan bahwasannya perubahan perilaku yang terjadi yaitu saat ini masyarakat mulai menyadari dengan pentingnya Perilaku Hidup Bersih dan Sehat (PHBS) seperti mencuci tangan menggunakan handsanitizer atau menggunakan sabun diair mengalir dan menyadari untuk patuh menjalakan protokol kesehatan yang ditetapkan oleh pemerintah terutama ketika berada diluar rumah seperti menggunakan masker, menjaga jarak, dan melaksanakan social and physical distancing. Namun masih banyak juga masyarakat yang belum mematuhi Perilaku Hidup Bersih dan Sehat (PHBS) dan ditemukan juga banyak dari perilaku masyarakat yang tidak sesuai dengan protokol kesehatan yang ditetapkan sedangkan dari data Covid-19 di Kabupaten Kuantan Singingi, terdapat beberapa masyarakat yang terpapar oleh Covid-19.

Berdasarkan latar belakang tersebut, peneliti tertarik untuk meneliti Faktor-Faktor yang Mempengaruhi Perilaku Masyarakat Terhadap Penggunaan APD (Alat Pelindung Diri) Pada Masa Covid-19 di Desa Suka Maju, Kec. Singingi Hilir, Kab. Kuantan Singingi, Prov. Riau

\section{METODE PENELITIAN}

Penelitian ini dilaksanakan di di Desa Suka Maju, Kec. Singingi Hilir, Kab. Kuantan Singingi, Prov. Riau, sampel yang diambil adalah adalah masyarakat yang berusia 1545 tahun yaitu 100 orang. Teknik pengumpulan data yaitu melakukan wawancara langsung kepada masyarakat yang sudah di tetapkan menjadi sampel. Instrumen yang digunakan adalah dengan menggunaakan Kuesioner dengan menggunakan uji Chi-Square dengan derajat kepercayaan sebesar $95 \%$.

\section{HASIL}

Tabel 1 karakteristik usia responden 1530 dengan 31-45 memiliki nilai frequency yang sama yaitu 50 orang dengan percent yang sama sebanyak 50\%. Karakteristik jenis kelamin mayoritas laki-laki sebanyak 53 orang dengan percent sebanyak 53\%. Karakteristik pendidikan terakhir mayoritas SMA/Sederajat sebanyak 58 orang dengan percent sebanyak $58 \%$. Karakteristik status pekerjaan mayoritas berstatus bekerja sebanyak 53 orang dengan percent sebanyak 53\%. Karakteristik status pernikahan berstatus menikah sebanyak 66 orang dengan percent $66 \%$.

Tabel 1 Karakteristik Responden Terhadap Faktor-Faktor Yang Mempengaruhi Perilaku Masyarakat Terhadap Penggunaan APD

\begin{tabular}{|c|c|c|c|}
\hline NO & KARAKTERISTIK & $\mathbf{F}$ & PRECENT \\
\hline \multirow[t]{2}{*}{1} & $\begin{array}{l}\text { USIA } \\
15-30 \\
31-44\end{array}$ & $\begin{array}{l}50 \\
50\end{array}$ & $\begin{array}{l}50 \\
50\end{array}$ \\
\hline & Total & 100 & 100 \\
\hline \multirow[t]{2}{*}{2} & $\begin{array}{l}\text { JENIS KELAMIN } \\
\text { Laki-laki } \\
\text { Perempuan }\end{array}$ & $\begin{array}{l}53 \\
47 \\
\end{array}$ & $\begin{array}{l}53 \\
47 \\
\end{array}$ \\
\hline & Total & 100 & 100 \\
\hline \multirow[t]{2}{*}{3} & $\begin{array}{l}\text { PENDIDIKAN } \\
\text { TERAKHIR } \\
\text { SD } \\
\text { SMP/Sederajat } \\
\text { SMA/Sederajat } \\
\text { D1-D3 } \\
\text { D4-S1 }\end{array}$ & $\begin{array}{c}6 \\
17 \\
58 \\
2 \\
17\end{array}$ & $\begin{array}{c}6 \\
17 \\
58 \\
2 \\
17\end{array}$ \\
\hline & Total & 100 & 100 \\
\hline \multirow[t]{2}{*}{4} & $\begin{array}{l}\text { STATUS } \\
\text { PEKERJAAN } \\
\text { Bekerja } \\
\text { Tidak Bekerja }\end{array}$ & $\begin{array}{l}53 \\
47\end{array}$ & $\begin{array}{l}53 \\
47\end{array}$ \\
\hline & Total & 100 & 100 \\
\hline 5 & $\begin{array}{l}\text { STATUS } \\
\text { PERNIKAHAN } \\
\text { Menikah } \\
\text { Belum Menikah }\end{array}$ & $\begin{array}{l}66 \\
34\end{array}$ & $\begin{array}{l}66 \\
34\end{array}$ \\
\hline
\end{tabular}




\begin{tabular}{l|l|l|l}
\hline & Total & 100 & $100 \%$ \\
\hline
\end{tabular}

Tabel 2 responden menunjukkan bahwa mayoritas responden memiliki faktor predisposisi yang patuh sebanyak 79 orang dimana sebanyak 74 orang $(93,7 \%)$ menggunakan APD sebanyak 5 Orang $(6,3 \%)$ tidak patuh menggunakan APD.

Tabel 2 Faktor Predisposisi Perilaku Masyarakat Terhadap Pengguanaan APD Di Masa Pandemic Covid-19.

\begin{tabular}{|c|c|c|c|c|c|}
\hline \multirow{2}{*}{\multicolumn{3}{|c|}{ FAKTOR PERILAKU }} & \multicolumn{2}{|c|}{$\begin{array}{c}\text { PENGGUNAAN } \\
\text { APD }\end{array}$} & \multirow[t]{2}{*}{$\begin{array}{c}\text { Tota } \\
\text { I }\end{array}$} \\
\hline & & & & & \\
\hline & & & & Patuh & \\
\hline \multirow{7}{*}{$\begin{array}{l}\text { Pr } \\
\text { ed } \\
\text { is } \\
\text { po } \\
\text { si } \\
\text { si }\end{array}$} & \multirow{3}{*}{$\begin{array}{l}\text { Bai } \\
k\end{array}$} & Count & 74 & 5 & 79 \\
\hline & & $\begin{array}{l}\text { Expected } \\
\text { Count }\end{array}$ & 61.6 & 17.4 & 79.0 \\
\hline & & $\begin{array}{l}\text { \% within } \\
\text { Predisposisi }\end{array}$ & $\begin{array}{r}93.7 \\
\%\end{array}$ & $6.3 \%$ & $\begin{array}{r}100 . \\
0 \%\end{array}$ \\
\hline & \multirow{4}{*}{$\begin{array}{l}\text { Tid } \\
\text { ak } \\
\text { Ba }\end{array}$} & Count & 4 & 17 & 21 \\
\hline & & $\begin{array}{l}\text { Expected } \\
\text { Count }\end{array}$ & 16.4 & 4.6 & 21.0 \\
\hline & & $\%$ within & 19.0 & $81.0 \%$ & 100. \\
\hline & & Predisposisi & $\%$ & & $0 \%$ \\
\hline \multirow{4}{*}{\multicolumn{2}{|c|}{ Total }} & Count & 78 & 22 & 100 \\
\hline & & $\begin{array}{l}\text { Expected } \\
\text { Count }\end{array}$ & 78.0 & 22.0 & $\begin{array}{r}100 . \\
0\end{array}$ \\
\hline & & $\%$ within & 78.0 & $22.0 \%$ & 100. \\
\hline & & Predisposisi & $\%$ & & $0 \%$ \\
\hline
\end{tabular}

Tabel 3 responden menunjukkan bahwa mayoritas responden memiliki faktor pemungkin dimana sebanyak $95 \%$ patuh dan berperilaku tidak patuh $4,3 \%$.

Tabel 3 Faktor Pemungkin Perilaku Masyarakat Terhadap Pengguanaan APD Di Masa Pandemic Covid-19

\begin{tabular}{|c|c|c|c|c|c|}
\hline & \multirow{2}{*}{\multicolumn{2}{|c|}{ FAKTOR PERILAKU }} & \multicolumn{2}{|c|}{$\begin{array}{l}\text { PENGGUNAAN } \\
\text { APD }\end{array}$} & \multirow[t]{2}{*}{ Total } \\
\hline & & & Patuh & $\begin{array}{l}\text { Tidak } \\
\text { Patuh }\end{array}$ & \\
\hline \multirow{3}{*}{\multicolumn{2}{|c|}{ Baik }} & Count & 22 & 1 & 23 \\
\hline & & $\begin{array}{l}\text { Expected } \\
\text { Count }\end{array}$ & 17.9 & 5.1 & 23.0 \\
\hline & & $\begin{array}{l}\% \text { within } \\
\text { Enabling }\end{array}$ & $95.7 \%$ & $4.3 \%$ & $100.0 \%$ \\
\hline lin & \multirow{3}{*}{$\begin{array}{l}\text { Tidak } \\
\text { Baik }\end{array}$} & Count & 56 & 21 & 77 \\
\hline $\mathbf{g}$ & & $\begin{array}{l}\text { Expected } \\
\text { Count }\end{array}$ & 60.1 & 16.9 & 77.0 \\
\hline & & $\begin{array}{l}\text { \% within } \\
\text { Enabling }\end{array}$ & $72.7 \%$ & $27.3 \%$ & $100.0 \%$ \\
\hline \multirow[t]{3}{*}{ Total } & & Count & 78 & 22 & 100 \\
\hline & & $\begin{array}{l}\text { Expected } \\
\text { Count }\end{array}$ & 78.0 & 22.0 & 100.0 \\
\hline & & $\begin{array}{l}\% \text { within } \\
\text { Enabling }\end{array}$ & $78.0 \%$ & $22.0 \%$ & $100.0 \%$ \\
\hline
\end{tabular}

Tabel 4 responden menunjukkan bahwa mayoritas responden memiliki faktor penguat perilaku yang patuh sebanyak 70 orang dimana sebanyak $93,3 \%$ patuh menggunakan APD sebanyak 30 orang dimana sebanyak $6,7 \%$ tidak patuh menggunakan APD

Tabel 4 Faktor Penguat Perilaku Masyarakat Terhadap Pengguanaan APD Di Masa Pandemic Covid-19

\begin{tabular}{|c|c|c|c|c|c|}
\hline \multirow{2}{*}{\multicolumn{3}{|c|}{ FAKTOR PERILAKU }} & \multicolumn{2}{|c|}{$\begin{array}{c}\text { PENGGUNAAN } \\
\text { APD }\end{array}$} & Total \\
\hline & & & Pacu & & \\
\hline \multirow{8}{*}{$\begin{array}{l}\text { Rein } \\
\text { forci } \\
\text { ng }\end{array}$} & \multirow{4}{*}{ Baik } & Count & 28 & 2 & 30 \\
\hline & & $\begin{array}{l}\text { Expected } \\
\text { Count }\end{array}$ & 23.4 & 6.6 & 30.0 \\
\hline & & $\%$ within & 93.3 & $6.7 \%$ & 100.0 \\
\hline & & $\begin{array}{l}\text { Reinforci } \\
\text { ng }\end{array}$ & $\%$ & & $\%$ \\
\hline & \multirow{4}{*}{$\begin{array}{l}\text { Tida } \\
\mathrm{k} \\
\text { Baik }\end{array}$} & Count & 50 & 20 & 70 \\
\hline & & $\begin{array}{l}\text { Expected } \\
\text { Count }\end{array}$ & 54.6 & 15.4 & 70.0 \\
\hline & & $\%$ within & 71.4 & $28.6 \%$ & 100.0 \\
\hline & & $\begin{array}{l}\text { Reinforci } \\
\text { ng }\end{array}$ & $\%$ & & $\%$ \\
\hline \multirow[t]{4}{*}{ Total } & & Count & 78 & 22 & 100 \\
\hline & & $\begin{array}{l}\text { Expected } \\
\text { Count }\end{array}$ & 78.0 & 22.0 & 100.0 \\
\hline & & $\%$ within & 78.0 & $22.0 \%$ & 100.0 \\
\hline & & $\begin{array}{l}\text { Reinforci } \\
\text { ng }\end{array}$ & $\%$ & & $\%$ \\
\hline
\end{tabular}

\section{PEMBahasan}

\section{Faktor Predisposisi Perilaku Masyarakat Terhadap Pengguanaan APD Di Masa Pandemic Covid-19}

Hasil penelitian didapatkan pada faktor predisposisi responden berkelakuan baik dan patuh dalam penggunaan APD sebanyak 74 orang, tetapi meskipun banyak responden yang berkelakuan baik pada faktor predisposisi masih dijumpai responden yang tidak patuh dalam penggunaan APD, yaitu sebanyak 5 orang. Dan pada faktor predisposisi responden yang berkelakuan tidak baik dan tidak patuh dalam penggunaan APD sebanyak 22 orang, meskipun demikian masih ada responden yang patuh dalam penggunaan APD sebanyak 4 orang. Maka dari hasil yang didapatkan responden yang Patuh sebanyak 78 orang dan tidak patuh dalam 22 orang. Faktor predisposisi yang mempengaruhi 
perilaku masyarakat yaitu pengetahuan dan sikap tentang kesehatan, kebiasaanserta kepercayaan masyarakat, nilai dan budaya yang dianut, tingkat pendidikan, status sosial ekonomi (Notoatmodjo, 2012:18) dalam Azizah. H. M. 2017).

Perilaku merupakan fungsidari faktor predisposisi yaitu faktor yang ada dalam diri individu yang ada didalamnya terdapat sikap dari individu. Sikap responden mempengaruhi tindakan responden dalam menggunakan APD di tempat kerja. Sikap terhadap perilaku menggunakan APD pada penelitian ini lebih banyak positif. Hasil penelitian sebelumnya menunjukkan pengetahuan masyarakat Kabupaten Wonosobo tentang Covid19 beradapada kategori Baik (90\%) dan hanya $10 \%$ berada pada kategori cukup. Untuk perilaku masyarakat Kabupaten Wonosobo terkait Covid19 menunjukkan perilaku yang baik sebanyak $95,8 \%$ dan hanya $4,2 \%$ masyarakat berperilaku cukup baik. Terdapat hubungan bermakna antara pengetahuan dengan perilaku masyarakat tentang Covid-19 dengan p-value 0,047 $(<0,05)$. (Dewi. I. P, 2020).

Pengetahuan masyarakat Desa Suka Maju terhadap Covid-19 menunjukkan angka 79\% dengan kategori tahu. Dan responden dengan kategori tidak tahu menunjukkan angka $21 \%$. Untuk sikap responden menunjukkan angka $78 \%$ dengan kategori baik dan kategori tidak baik sebanyak $22 \%$. Dan untuk persepsi responden dengan kategori baik menunjukkan angka $78 \%$ dan kategori tidak baik pada angka $22 \%$.

Asumsi Peneliti bahwasannya faktor predisposisii berpengaruh terhadap perilaku masyarakat dalam penggunaan APD dimasa pandemic Covid-19. Dapat dilihat dari hasil penelitian bahwasannya responden yang berkelakuan baik dan patuh dalam penggunaan APD sebanyak 74 orang

Faktor Pemungkin Perilaku Masyarakat Terhadap Penggunaan APD Dimasa Pandemi Covid-19
Hasil penelitian yang didapatkan yaitu faktor pemungkin atau enabling factor ditemukan sebanyak 78 responden patuh terhadap penggunaan APD. Responden yang berkelakuan tidak patuh dalam penggunaan APD sebanyak 22 orang. Dan pada faktor ini juga ditemukan responden yang berkelakuan baik dan patuh terhadap penggunaan APD sebanyak 22 orang dengan responden yang patuh dalam penggunaan APD dan tidak baik dalam penggunaan APD sebanyak 56 orang. Responden yang tidak patuh dan berkelakuan baik sebanyak 1 orang dan yang tidak patuh dan tidak berkelakuan baik sebanyak 21 orang.

Hasil penelitian ini sejalan dengan penelitian Dewi yang menyatakan bahwa ketersediaan fasilitas memiliki hubungan signifikan dengan kepatuhan penggunaan alat pelindung diri pada mahasiswa profesi dokter gigi di Rumah Sakit Gigi dan Mulut Universitas Jenderal Soedirman. Green menyatakan bahwa salah satu faktor yang mempengaruhi perilaku yaitu faktor pendukung (enabling factor) yang salah satunya yaitu ketersediaan fasilitas yang dalam hal ini yaitu tersedianya alat pelindung diri yang baik dan lengkap. Tersedianya alat pelindung diri ini merupakan salah satu cara untuk dapat memfasilitasi responden untuk dapat menggunakan alat pelindung diri dengan lengkap untuk melakukan tindakan perawatan (Dewi. I. P. dkk, 2020).

Pandangan masyarakat terhadap enabling factor menunjukkan angka 30\% responden dengan kategori baik sedangkan $70 \%$ responden berkategori tidak baik.Asumsi peneliti bahwasannya faktor enebling tidak berpengaruh terhadap perilaku masyarakat dalam penggunaan APD dimasa pandemic Covid-19 di Desa Suka Maju, Kec. Singingi Hilir, Kab. Kuantan Singingi, Prov. Riau, dengan ditandai adanya responden yang berkelakuan tidak baik namun patuh dalam penggunaan APD.

\section{Faktor Penguat Perilaku Masyarakat Terhadap Penggunaan APD Dimasa Pandemi Covid-19}


Hasil yang didapatkan yaitu faktor penguat atau reinforcing factor ditemukan sebanyak 78 responden patuh dalam penggunaan APD dan responden yang tidak patuh sebanyak 22 orang. Pada factor ini ditemukan responden yang berkelakuan baik dan patuh dalam penggunaan APD sebanyak 28 orang, dan responden yang tidak patuh dalam penggunaan APD dan berkelakuan baik sebanyak 2 orang. Dan yang tidak patuh dan tidak berkelakuan baik sebanyak 20 orang, responden yang patuh dan berkelakuan tidak baik sebanyak 50 orang.

Menurut teori Lawrence Green faktor faktor pendorong merupakan faktor dari diluar individu yang membentuk bentuk sikap dan perilaku dari petugas kesehatan, kelompok referensi, tokoh masyarakat dan agama, peraturan atau norma yang ada. Faktor ini meliputi sosial sikap dan perilaku tokoh masyarakat, tokoh agama, sikap dan perilaku petugas termasuk petugas kesehatan.(Notoatmodjo, 2012:19) dalam Azizah. H. M. 2017).

Hasik penelitian yang dilakukan oleh Herdiana Ningsih di RSUD Kab. Mamuju didapatkan hasil bahwa ada hubungan yang signifikan antara kebijakan dengan perilaku penggunaan APD dengan nilai $p(0,000)<$ 0,05. (Ningsih. H. 2018)

Pandangan masyarakat terhadap reinforcing factor menunjukkan angka 30\% responden dengan kategori baik sedangkan $70 \%$ responden berkategori tidak baik. Asumsi penelitian bahwasannya factor reinforcing tidak berhubungan terhadap perilaku masyarakat dalam penggunaan APD dimasa pandemic Covid-19 di Desa Suka Maju, Kec. Singingi Hilir, Kab. Kuantan Singingi, Prov. Riau. Dengan ditandai adanya responden yang berkelakuan tidak baik namun patuh terhadap penggunaan APD.

\section{KESIMPULAN DAN SARAN}

\section{KESIMPULAN}

1. Jumlah responden usia 15-30 tahun dan 31-45 tahun sama banyaknya yaitu masing-masing 50 responden. Jumlah responden berjenis kelamin laki-laki lebih banyak daripada responden berjenis kelamin perempuan yaitu 53 orang. Jumlah responden dengan pendidikan terakhir SMA/Sederajat lebih banyak daripada pendidikan terakhir SD, SMP/Sederajat, D1-D3, dan D4-S1. Yaitu sejumlah 58 orang. Jumlah responden dengan status pekerjaan bekerja lebih banyak daripada responden dengan status tidak bekerja. Yaitu sejumlah 53 orang.

2. Berdasarkan factor perilaku yang terdiri dari factor predisposisi, enabling factor, dan reinforcing factor, maka didapatkan responden yang patuh dalam penggunaan APD didapat responden yang berperilaku baik pada factor predisposisi, dengan jumlah responden yang patuh dan berkelakuan baik sebanyak 74 orang.

\section{DAFTAR PUSTAKA}

Azizah, M. H. (2016). Faktor yang Berhubungan dengan Perilaku Keselamatan Berkendara (Safety Riding) pada Mahasiswa. Kesehatan Masyarakat UNNES, 3(2), 23-24. http://lib.unnes.ac.id/25674/1/641141 1011.pdf

Dewi, I. P., Adawiyah, W. R., \& Rujito, L. (2020). Analisis Tingkat Kepatuhan Pemakaian Alat Pelindung Diri Mahasiswa Profesi Dokter Gigi Di Rumah Sakit Gigi Dan Mulut Unsoed. Jurnal Ekonomi, Bisnis, Dan Akuntansi, 21(4). https://doi.org/10.32424/jeba.v21i4.15 41

Ningsih, Herdiana. (2018). Faktor Yang Berhubungan Dengan Penggunaan Alat Pelindung Diri Pada Perawat Di Instalasi Rawat Inap Rsud Kabupaten Mamuju Sulawesi Barat. Fakultas Kesehatan Masyarakat. Universitas Hasanuddin 
Makasar.

JHU CSSE COVID-19. (2021). Penyakit Coronavirus (COVID-19) Di Indonesia. Diakses pada 24 Februari 2021, pada https://g.co/kgs/9WFvEQ

Kementerian Kesehatan Republik Indonesia. (2020). Gerakan Masyarakat Hidup Sehat. Apa Yang Harus Dilakukan Masyarakat Untuk Cegah Penularan Covid-19. 2020, 1-24.

Kesehatan Kesehatan (2020). Pedoman Pencegahan dan Pengendalian Corona Virus deases (Covid-19). Kementrian Kesehatan, 5, 178. https://covid19.go.id/storage/app/medi a/Protokol/REV-

05_Pedoman_P2_COVID-

19_13_Juli_2020.pdf

Malik, F., Bafadal, M., Wahyuni, \& Sahidin. (2020). Edukasi Perilaku Hidup Bersih dan Sehat (PHBS), Gerakan Menggunakan Masker (GEMAS), serta penggunaan antiseptik dan desinfektan di Desa La Nipa Nipa, Kecamatan Katoi, Kolaka Utara, Provinsi Sulawesi Tenggara. Jurnal Pengabdian Masyarakat, 1(3), 154-159. http://jppipa.unram.ac.id/index.php/jp $\mathrm{mpi} /$ article/view/440

Ningsih, M. U. Mujiburrahman, Riyadi, M. E., \& (2020). Pengetahuan Berhubungan dengan Peningkatan Perilaku Pencegahan COVID-19 di Masyarakat. Jurnal Keperawatan Terpadu, 2(2), 130-140.

http://www.elsevier.com/locate/scp

Octaviani. R (2020). Pengaruh Pengetahuan Dan Perilaku Masyarakat Terhadap Penerapan Pembatasan Sosial Berskala Besar Dalam Pandemi Covid-19 Di Indonesia. Jurusan Teknik Industri. Fakultas Teknik. Universitas Andalas Padang.

riauonline.co.id. (2020). Warga Batam Positif
Covid-19, Sempat Dua Bulan Tinggal Di Kuansing. Diakses pada 08 Maret 2021, dari

https://www.riauonline.co.id/riau/ranta u-kuantan/read/2020/06/10/wargabatam-positif-covid-19-sempat-duabulan-tinggal-di-kuansing

Riyanto, Agus, 2011, Aplikasi Metodologi Penelitian Kesehatan, Nuha Medika, Yogyakarta

Rosidin, U., Rahayuwati, L., \& Herawati, E. (2020). Perilaku dan Peran Tokoh Masyarakat dalam Pencegahan dan Penanggulangan Pandemi Covid -19 di Desa Jayaraga, Kabupaten Garut. Umbara, $5(1), \quad 42$. https://doi.org/10.24198/umbara.v5i1. 28187

World Health Organization. (2021, 27 Februari). WHO Coronavirus (COVID19) Dashboard. Diakses pada 27 Februari 2021, dari https://covid19.who.int/ 